\title{
Life cycle and spring phenology of Temora longicornis in the Baltic Sea
}

\author{
J. Dutz ${ }^{1,3, *}$, V. Mohrholz ${ }^{1}$, J. E. E. van Beusekom² \\ ${ }^{1}$ Leibniz Institute for Baltic Sea Research Warnemünde, Seestrasse 15, 18119 Rostock, Germany \\ ${ }^{2}$ Alfred Wegener Institute for Polar and Marine Research, Wadden Sea Station Sylt, Hafenstrasse 43, 25992 List/Sylt, Germany \\ ${ }^{3}$ Present address: Technical University of Denmark, National Institute of Aquatic Resources, Kavalergården 6, \\ 2920 Charlottenlund, Denmark
}

\begin{abstract}
The seasonal variation in abundance, biomass and vertical distribution of nauplii and copepodites of Temora longicornis in the Bornholm Basin was studied from March 2002 to May 2003 to understand the overwintering, spring development and life cycle of this species in the Baltic Sea. The analysis of the life cycle by means of stage structure, copepodite length and stage duration revealed that $T$. longicornis produced 5 to 6 generations $\mathrm{yr}^{-1}$. The species overwintered in low abundance as an active, slowly developing generation with adults appearing from February/March onwards. The onset of the spring bloom in April triggered reproduction and initiated the first spring generation $\left(\mathrm{G}_{1}\right)$ with a strong rise in nauplii abundance. The stock biomass increased in May with the occurrence of the copepodites of $\mathrm{G}_{1}$ and remained high during the succeeding generations $\mathrm{G}_{2}$ and $\mathrm{G}_{3}$ until August. The stock was distributed in the upper, brackish 30 to $60 \mathrm{~m}$ of the water column. In summer, copepodite stages concentrated in the cool intermediate water during daytime and migrated to the surface at night. This seasonal submergence explains the persistence of $T$. longicornis in the Bornholm Basin throughout the year because the average temperature experienced by the population was low $\left(5\right.$ to $\left.14^{\circ} \mathrm{C}\right)$ compared with the unfavourable warm surface temperatures $\left(>20^{\circ} \mathrm{C}\right)$. The study further showed that the timing of the spring biomass increase of the species is associated with the maturation of the first generation and can vary considerably between years. A delay of $\sim 1$ mo was observed in 2003 when environmental conditions during the cohort development were unfavourable. We conclude that the spring development of $T$. longicornis is complex and depends not only on prevailing temperatures, but also on spring bloom timing and post-bloom food availability.
\end{abstract}

KEY WORDS: Population dynamics $\cdot$ Phenology $\cdot$ Temora longicornis $\cdot$ Vertical distribution $\cdot$ Food Temperature $\cdot$ Baltic Sea

Resale or republication not permitted without written consent of the publisher

\section{INTRODUCTION}

In the last 2 decades, evidence that climate variability can have a strong impact on the diversity and community structure of marine ecosystems in the North Atlantic and its adjacent seas has grown (e.g. Beaugrand et al. 2002, Richardson 2008). Also in the brackish Baltic Sea, the alteration of the pelagic ecosystem involving phytoplankton, zooplankton and fish has been documented together with changes in the physical environment (Dippner et al. 2008). Long-term monitoring programmes have observed large inter-annual and inter-decadal fluctuations in the abundance and biomass of pelagic zooplankton. In coastal areas and the Gulf of Finland, the abundance of copepods of marine origin, such as Temora longicornis and Pseudocalanus spp., generally declined in favour of brackish or freshwater copepods, rotifers and cladocerans (Viitasalo et al. 1995, Ojaveer et al. 1998, Vuorinen et al. 1998). Large changes in the composition of the zooplankton also occurred in the open central Baltic Sea. Here, a steady decrease in the abundance of the formerly dominant species Pseudocalanus spp. since the late 1980s contrasts with the increasing abundance of 
T. longicornis and Acartia spp. (Dippner et al. 2000, Möllmann et al. 2000). Changes in species composition and biomass were also recorded in the phytoplankton and fish fauna, which has recently been interpreted as a shift in the ecological state of the Baltic Sea (e.g. Alheit et al. 2005).

Oceanographic and hydrological factors appear to be the principal control on the variations in the abundance of copepod species of marine origin in the Baltic Sea (Dippner et al. 2008). Temora longicornis, for instance, has a wide geographical distribution in areas ranging from sub-tropical to sub-polar coastal marine waters (e.g. CPR Survey Team 2004). In the Baltic Sea, T. longicornis is a key species in the ecosystem and serves as the major diet for clupeid fish (Möllmann \& Köster 2002, Casini et al. 2004). Here, this euryhaline and eurythermal species occurs at its physiological limits with regard to salinity and is, therefore, found primarily in offshore waters (Hernroth \& Ackefors 1977, Viitasalo et al. 1995, Ojaveer et al. 1998). The abundance of $T$. longicornis in the Finish Archipelago Sea, the Gulf of Finland and the northern Baltic Proper correlates with seawater salinity, which has decreased in the last 2 decades due to increased precipitation and freshwater runoff (Viitasalo et al. 1995, Vuorinen et al. 1998, Hänninen et al. 2003). As a consequence, $T$. longicornis nearly disappeared in coastal areas and displayed a general westward shift in its distribution area (Ojaveer et al. 1998, Vuorinen et al. 1998). Other studies, using in part the same data but with a focus on long-term changes in the offshore basins, found primarily a positive correlation of $T$. longicornis biomass with surface water temperature particularly during the spring (Dippner et al. 2000, Möllmann et al. 2003). A significant correlation with salinity was found only during summer. Apart from hydrography, eutrophication and changes in the top-down control by planktivorous fishes, such as sprat Sprattus sprattus and herring Clupea harengus, may also affect the population dynamics of the Baltic zooplankton, although at present their contribution to the long-term variations in the biomass of $T$. longicornis is uncertain (e.g. Flinkman et al. 1998, Möllmann \& Köster 2002, Casini et al. 2009). Hydrographic conditions are generally found to be sufficient in explaining the long-term variation in the standing stocks of $T$. longicornis (Vuorinen et al. 2003, Dippner et al. 2008).

Seawater properties in the Baltic Sea depend strongly on the prevailing climatic conditions over northern Europe (Dippner et al. 2000, Hänninen et al. 2000), which suggests climate variability controls Temora longicornis biomass (Hänninen et al. 2003, Möllmann et al. 2003). During the positive phase of the North Atlantic Oscillation (NAO) relatively mild winters with above average surface water temperatures in winter/spring prevail, while the seawater salinity decreases due to increased precipitation and freshwater run-off (Hänninen et al. 2000, MacKenzie et al. 2007). In contrast to the straightforward effect of climate variability on the hydrographic condition in the Baltic Sea, the mechanisms and processes that relate the observed environmental changes to the long-term changes in the abundance of $T$. longicornis are unknown. It is assumed that hydrographic factors immediately affect wintertime survival and springtime reproduction, which are favoured by a higher salinity and temperature (Dippner et al. 2000, Hänninen et al. 2003, Möllmann et al. 2003). However, present knowledge on the life cycle and population dynamics of $T$. longicornis in the open Baltic Sea lacks the required detail to fully describe the effect of physical forcing. While some early work by Hernroth \& Ackefors (1977) provides a general overview on the seasonal variation of the species biomass, later work (e.g. Hansen et al. 2006) focused mainly on coastal areas or specific periods in late spring and summer.

Here, we report the variation in abundance, biomass and vertical distribution of nauplii and copepodites of Temora longicornis, which was investigated with a high temporal resolution from March 2002 to May 2003 in the Bornholm Basin of the central Baltic Sea. The seasonal dynamics of the population are described in relation to the physical and food environment, and a life cycle of the species, consistent with observation, in the Bornholm Basin is proposed.

\section{MATERIALS AND METHODS}

Study site. The investigation was performed onboard the RV 'Heincke' (Alfred Wegener Institute, Bremerhaven), RV 'Alkor' (Research Center for Marine Geosciences [GEOMAR], Kiel) and RV 'Alexander von Humboldt' (Institute for Baltic Sea Research, Rostock) during a series of cruises to the Bornholm Sea from March 2002 to May 2003 as part of the German Global Ocean Ecosystem Dynamics (GLOBEC) programme (Table 1). Samples were collected at approximately biweekly to monthly intervals from a rectangular station grid with a mean resolution of about 8 nautical miles. At 9 stations with water depths ranging from 61 to $97 \mathrm{~m}$, samples for CTD, seston, vertically integrated zooplankton (Bongo net) and depth stratified zooplankton (Multinet) were taken (Fig. 1). Sampling was generally completed within 4 to $6 \mathrm{~d}$ except in winter $2002 / 2003$ when the number of stations was reduced due to bad weather conditions.

Sampling. At each station, samples for hydrography and micro- and mesozooplankton were taken. A standard CTD probe (SeaBird 911+ or ADM) was lowered 
Table 1. Overview of cruise dates to the Bornholm Sea, the number of stations sampled for zooplankton profiles, minimum, maximum and mean standing stock of nauplii (Stages $\mathrm{N}_{1}$ to $\mathrm{N}_{6}$, no. ind. $\mathrm{m}^{-2}$ ) and copepodites (Stages $\mathrm{C}_{1}$ to $\mathrm{C}_{6}$, no. ind. $\mathrm{m}^{-2}$ ) during March 2002 to May 2003

\begin{tabular}{|c|c|c|c|c|c|c|c|}
\hline \multirow{2}{*}{ Sampling date } & \multirow{2}{*}{$\begin{array}{c}\text { No. of profiles } \\
\text { (Multinet/ } \\
\text { Bongo net) }\end{array}$} & \multicolumn{3}{|c|}{ Naunlii } & \multicolumn{2}{|r|}{ - Copepodites } & \multirow[b]{2}{*}{ Mean } \\
\hline & & $\mathrm{N}_{\min }$ & $\mathrm{N}_{\max }$ & Mean & $\mathrm{C}_{\min }$ & $\mathrm{C}_{\max }$ & \\
\hline 17-19 Mar 2002 & $5 / 6$ & 860 & 18676 & 6199 & 11598 & 35789 & 19939 \\
\hline $04-07$ Apr 2002 & $9 / 9$ & 18480 & 152340 & 73196 & 5648 & 19631 & 10434 \\
\hline 19-22 Apr 2002 & $9 / 9$ & 29048 & 602912 & 283286 & 2324 & 27658 & 12113 \\
\hline 06-09 May 2002 & $9 / 9$ & 40928 & 245232 & 121127 & 52925 & 232370 & 135502 \\
\hline 23-28 May 2002 & $9 / 9$ & 53408 & 219664 & 145068 & 375851 & 1982295 & 1178068 \\
\hline 12-17 Jun 2002 & $9 / 9$ & 2880 & 92672 & 21944 & 324074 & 1214293 & 700970 \\
\hline 02-05 Jul 2002 & $-/ 9$ & - & - & - & 264336 & 1347575 & 721703 \\
\hline 23-27 Jul 2002 & $9 / 9$ & 44528 & 283615 & 166234 & 216801 & 1166312 & 456395 \\
\hline 13-16 Aug 2002 & $8 / 9$ & 9632 & 286336 & 95767 & 106141 & 419361 & 229111 \\
\hline 04-08 Sep 2002 & $9 / 9$ & 6476 & 149904 & 61592 & 67997 & 191327 & 147025 \\
\hline $02-10$ Oct 2002 & $9 / 7$ & 160448 & 451588 & 272489 & 33264 & 624223 & 199622 \\
\hline 13-16 Nov 2002 & $9 / 9$ & 43517 & 113008 & 82660 & 87993 & 302512 & 168992 \\
\hline 14-22 Jan 2003 & $9 / 6$ & 852 & 10176 & 4008 & 33145 & 80913 & 49833 \\
\hline 11-18 Feb 2003 & $9 / 9$ & 1288 & 11964 & 4164 & 26172 & 35496 & 32628 \\
\hline 10-15 Mar 2003 & $9 / 9$ & 5120 & 30104 & 16836 & 25199 & 50160 & 29269 \\
\hline 18-22 Apr 2003 & $9 / 9$ & 242304 & 518848 & 341475 & 8104 & 103864 & 22838 \\
\hline 21-29 Мay 2003 & $9 / 9$ & 27632 & 701888 & 247698 & 83374 & 261666 & 204577 \\
\hline
\end{tabular}

from the surface to near the seabed to obtain vertical profiles of temperature and salinity. Additional vertical profiles for January and February 2002 were obtained from the database of the International Council for the Exploration of the Sea (ICES; available at www.ices.dk).

Seston samples for microplankton counts were taken with a rosette of Niskin bottles at discrete water depths and fixed with acidified Lugol's solution (2\% final concentration). About 25 to $50 \mathrm{ml}$ of the sample was concentrated in settling chambers according to the method described by Utermöhl (1958) and counted with an inverted microscope at 200 to $400 \times$ magnification. Organisms were classified into taxonomic categories and the cell dimensions of each category were

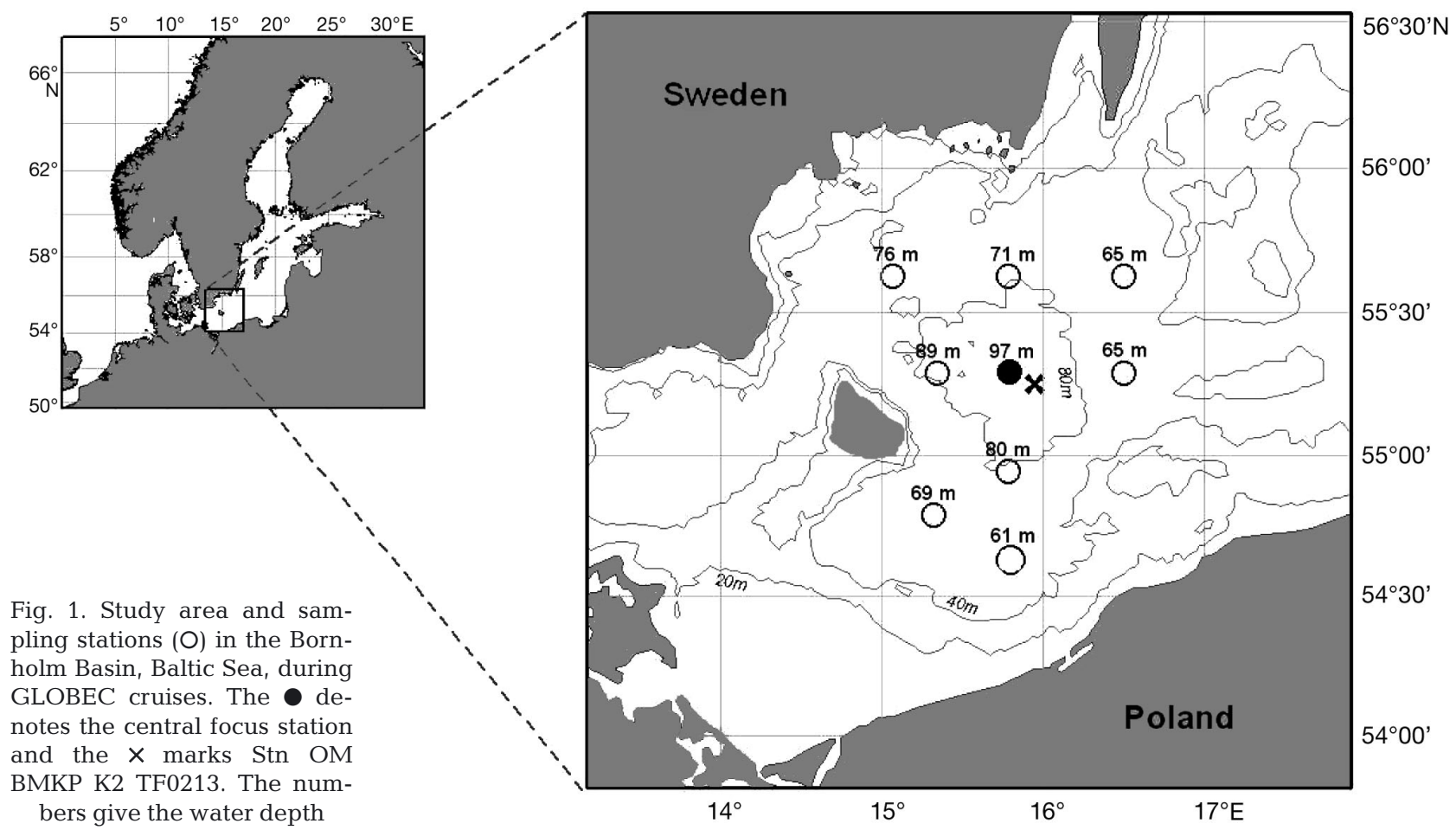


measured. Protist cell volume was converted to carbon biomass according to the methods used by Edler (1979) and Putt \& Stoecker (1989). Additional data for October 2002 and April-May 2003 was obtained from the HELCOM monitoring programme for Stn OM BMKP K2 (IOW Stn TF0213, see Wasmund et al. 2003), which is located close to the central focus station.

Zooplankton sampling was conducted using a Bongo net with a $0.12 \mathrm{~m}^{2}$ mouth opening and $150 \mu \mathrm{m}$ mesh size. Double-oblique hauls were taken from the surface to $5 \mathrm{~m}$ above the sea floor. The net was equipped with a calibrated flow meter and was towed horizontally at a ship speed of $1.5 \mathrm{~m} \mathrm{~s}^{-1}$ and vertically at $0.5 \mathrm{~m}$ $\mathrm{s}^{-1}$. Vertical samples were taken with a $0.25 \mathrm{~m}^{2}$ multiple opening and closing net (50 $\mu \mathrm{m}$ mesh size, Multinet, Hydrobios; vertical towing speed, $0.2 \mathrm{~m} \mathrm{~s}^{-1}$ ). The gear was lifted from $5 \mathrm{~m}$ above the sea floor to the surface in $10 \mathrm{~m}$ depth intervals except in April 2003 when a vertical resolution of $5 \mathrm{~m}$ was chosen for the central focus station. All zooplankton samples were preserved in borax-buffered formalin (4\% final concentration).

In the laboratory, the taxonomic composition was analysed with a compound microscope. The sample size was adjusted to provide at least 150 counts of Temora longicornis. Individuals were identified to nauplii, 5 copepodite stages $\left(\mathrm{C}_{1}\right.$ to $\left.\mathrm{C}_{5}\right)$ and adult females and males. For each sampling month, the length of 30 individuals was measured with a compound stereo microscope at 50 to $100 \times$ magnification (resolution, 10 to $20 \mu \mathrm{m})$. Fewer individuals were sized in months that had an insufficient number of stages (January to March in both 2002 and 2003). The measurements were converted to biomass using a lengthweight conversion factor established by Köster (2003). For nauplii, which were not separated by stage, a mean weight of $0.40 \mu \mathrm{g} C$ for $\mathrm{N}_{1}$ to $\mathrm{N}_{6}$ based on size measurements for January to May 2003 (J. Dutz unpubl. data) was used.

The abundance of copepodite stages $\mathrm{C}_{1}$ to $\mathrm{C}_{6}$ (no. ind. $\mathrm{m}^{-3}$ ) was estimated from the integrated Bongo net catches with zooplankton counts and filtered volumes derived from flow meter readings. The standing stock (no. ind. $\mathrm{m}^{-2}$ ) was calculated by multiplying the abundance with water depth. The standing stock of nauplii stages $\mathrm{N}_{1}$ to $\mathrm{N}_{6}$ (no. ind. $\mathrm{m}^{-3}$ ) was calculated from the vertical Multinet catches by accumulating the stocks for each depth interval, which was derived from nauplii counts, filtered volume and the length of the depth interval.

The vertical distribution of nauplii and copepodite stages was derived from Multinet samples. Due to the strong seasonal variation in the standing stock, the vertical distribution of development stages in day and night profiles was calculated and displayed as the percentage the stock in each depth contributed to the total standing stock. About $50 \%$ of the vertical profiles were taken either at day or at night, while the remaining $50 \%$ were taken at dusk and dawn. As a further index of the vertical distribution of the copepods, the weighted mean depth (WMD, Bollens \& Frost 1989) was computed for each vertical profile from the equation:

$$
\mathrm{WMD}=\frac{\sum \mathrm{n}_{i} d_{i}}{\sum \mathrm{n}_{i}}
$$

where $\mathrm{n}_{i}$ is the abundance of each stage (no. ind. $\mathrm{m}^{-3}$ ) in each depth stratum $i$ with the mean depth of $d_{i}$.

Construction of a life cycle of Temora longicornis. Data on abundance was combined with estimates of stage durations to construct a hypothetical life cycle of Temora longicornis for the observation period. For this, the occurrence of nauplii in samples was taken as a starting point to predict the development of a cohort from stage durations. When nauplii observed in the field temporally overlapped with the projected maturation of a preceding cohort, they were assigned to a new generation. By starting the projection in March 2002, a sequence of generations was constructed. The calculation of stage duration was based on Bělehrádek's functions for food saturation and limitation (Corkett \& McLaren 1970, Klein Breteler \& Gonzales 1986); the ranges of estimated durations and the average used for the prediction are reported in Table 2. Average food concentration and temperature values were used for those depths where $90 \%$ of the population at day and night were found (Table 2).

\section{RESULTS}

\section{Hydrography}

The water column in the Bornholm Basin was permanently stratified into a brackish surface layer with a salinity (S) of 7 to 8 (as measured on the practical salinity scale) extending to about $50 \mathrm{~m}$ depth above a bottom layer with $\mathrm{S}$ higher than 14 below $70 \mathrm{~m}$ and a halocline ranging from $\sim 45$ to $70 \mathrm{~m}$ (Fig. 2). In 2002, mild winter conditions with water temperatures of 3.1 to $3.3^{\circ} \mathrm{C}$ in January to March occurred. Temperatures rose to $9.8^{\circ} \mathrm{C}$ by the end of May and the seasonal thermocline $\left(\sim 7^{\circ} \mathrm{C}\right.$ isotherm) developed at $\sim 20 \mathrm{~m}$ depth within the brackish layer, which separated a warm upper surface and the cooler intermediate layer (Fig. 2a). During summer, surface temperatures exceeded $20^{\circ} \mathrm{C}$ in August and September. The autumn cooling eroded the thermal stratification and temperatures decreased to $3.8^{\circ} \mathrm{C}$ in January. In 2003 , the spring cooling was more intense than in 2002 and resulted in minimum temperatures of $1.7^{\circ} \mathrm{C}$ in the upper $30 \mathrm{~m}$ during March. Similar to 2002, the onset of the vertical stratification 
Table 2. Temora longicornis. Ranges of mean temperature $\left({ }^{\circ} \mathrm{C}\right)$ and average food concentration $\left(\mu \mathrm{C} \mathrm{C} l^{-1}\right)$ at the depth where $90 \%$ of the population were found and ranges of calculated stage duration for nauplii and copepodites (d stage ${ }^{-1}$ ) during March 2002 to May 2003. Stage duration is based on functions of generation time given by Corkett \& McLaren (1970) and Klein Breteler \&

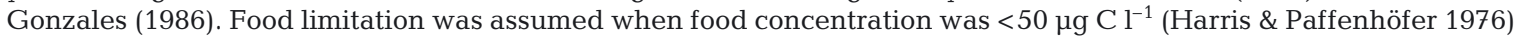

\begin{tabular}{|c|c|c|c|c|}
\hline Sampling date & $\begin{array}{l}\text { Temperature } \\
\left({ }^{\circ} \mathrm{C}\right)\end{array}$ & $\begin{array}{c}\text { Food concentration } \\
\left(\mu \mathrm{C} \mathrm{C} \mathrm{l}^{-1}\right)\end{array}$ & $\begin{array}{l}\text { Stage duration } \\
\left(\mathrm{d} \operatorname{stage}^{-1}\right)\end{array}$ & $\begin{array}{l}\text { Mean duration } \\
\left(\text { d stage }^{-1}\right)\end{array}$ \\
\hline Mar-early Apr 2002 & $3.3-3.6$ & $76-90$ & $6-7$ & 6 \\
\hline Early Apr-late Apr 2002 & $3.6-4.2$ & $120-315$ & $5-6$ & 5 \\
\hline Late Apr-early May 2002 & $4.2-5.5$ & $72-185$ & $4-6$ & 5 \\
\hline Early May-late May 2002 & $5.5-8.4$ & $69-112$ & $3-4$ & 4 \\
\hline Late May-mid-Jun 2002 & $8.4-8.8$ & $75-114$ & 3 & 3 \\
\hline Mid-Jun-early Jul 2002 & $8.8-8.4$ & $53-185$ & 3 & 3 \\
\hline Early Jul-late Jul 2002 & $8.4-10.1$ & $4.9-49$ & $4-5$ & 5 \\
\hline Late Jul-mid-Aug 2002 & $10.1-7.5$ & $11.6-46$ & $6-7$ & 7 \\
\hline Mid-Aug-early Sep 2002 & $7.5-10.4$ & $71-97$ & $2-4$ & 3 \\
\hline Early Sep—mid-Oct 2002 & $10.4-13.8$ & $11.2-114$ & $2-3$ & 2 \\
\hline Mid-Oct-mid-Nov 2002 & $13.8-8.9$ & 22.4 & $4-6$ & $5^{\mathrm{b}}$ \\
\hline Mid-Nov 2002-mid-Jan 2003 & $8.9-3.7$ & $3.2-7.2$ & $6-15$ & Nov 6, Dec $10^{c}$ \\
\hline Mid-Jan-mid-Feb 2003 & $3.7-3.1$ & $3.1-14.2$ & $15-23$ & $20^{\mathrm{b}}$ \\
\hline Mid-Feb-mid-Mar 2003 & $3.1-1.9$ & $13.8-26.8$ & $23-30$ & $20^{\mathrm{b}}$ \\
\hline Mid Mar-mid-Apr 2003 & $1.9-3.1$ & $102-281$ & $8-11$ & 9 \\
\hline Mid-Apr-early May 2003 & $3.1-6.4$ & $59-154$ & $4-6$ & 5 \\
\hline Early May-end May 2003 & $6.4-9.8$ & $(44-89)^{\mathrm{a}}$ & $7-8$ & $7^{\mathrm{b}}$ \\
\hline
\end{tabular}

took place during April-May when surface temperatures increased to $10^{\circ} \mathrm{C}$.

The hydrographical conditions in the intermediate and bottom water were mainly determined by several subsequent inflow events of saline water (Feistel et al. 2003, Mohrholz et al. 2006). In short, exceptionally warm water masses entered the Bornholm Basin in September at $60 \mathrm{~m}$ depth (temperature $[T], \sim 13^{\circ} \mathrm{C} ; \mathrm{S}$, $\sim 13)$ and in November at $90 \mathrm{~m}$ depth $\left(T, \sim 11.6^{\circ} \mathrm{C} ; \mathrm{S}\right.$, $\sim 16)$ and increased the temperature of the intermediate and the bottom water (Fig. 2b). This water was then replaced by a deep inflow of cold, saline water $(\mathrm{S},>17$; $T_{1}<4^{\circ} \mathrm{C}$ ) at the end of January. The series of inflows shifted the halocline/pycnocline (upper border $\mathrm{S}$, ca. 8; water density $\left[\sigma_{\mathrm{T}}\right], \sim 6$ ) upwards by $\sim 15 \mathrm{~m}$ and resulted in a shallower upper mixed layer in spring 2003 than in spring 2002.

\section{Protists}

The seasonal variation of the protist biomass in the upper $30 \mathrm{~m}$ of the water column showed 3 major periods: a spring maximum, an intermediate level during summer to early autumn and a winter minimum (Fig. 3a,b). In 2002, the annual biomass maximum had started to develop at the end of March and resulted in 2 successive peaks of 9.9 and $13.7 \mathrm{~g} \mathrm{C} \mathrm{m}^{-2}$ in April. The first maximum in early to mid-April consisted mainly of the diatom Skeletonema costatum, while the second in late April was formed by diverse ciliates, dinoflagellates and flagellates. Following the decline in May, the biomass fluctuated between 1.5 and $3.3 \mathrm{~g} \mathrm{C} \mathrm{m}^{-2}$ until September 2002 and mainly consisted of ciliates during May and during August to September, while cyanobacteria and nanoflagellates were abundant in June and July. During October 2002 to February 2003 the standing stock of protists was low $\left(<0.7 \mathrm{~g} \mathrm{C} \mathrm{m}^{-2}\right)$.

In 2003, the spring development of the protist biomass occurred earlier than in 2002. The spring bloom of Skeletonema costatum developed at the beginning of March. Both dinoflagellates and ciliates contributed substantially to the spring bloom. Biomass maxima of $8.6 \mathrm{~g} \mathrm{C} \mathrm{m}^{-2}$ were observed at the end of March followed by a decline $\left(6.5 \mathrm{~g} \mathrm{C} \mathrm{m}^{-2}\right)$ during April to an intermediate level at the beginning of May. In 2003, a peak of diverse ciliates similar to that in 2002 was not observed. Ciliate biomass was dominated by Myrionecta rubra. In both years, the protist biomass maximum developed at temperatures $<5^{\circ} \mathrm{C}$.

\section{Temora longicornis}

\section{Abundance, stage structure}

Temora longicornis nauplii $\left(\mathrm{N}_{1}\right.$ to $\left.\mathrm{N}_{6}\right)$ and copepodites $\left(\mathrm{C}_{1}\right.$ to $\left.\mathrm{C}_{6}\right)$ displayed irregular variations in stock size in each month, which fluctuated by a factor of 2 to 30 (Table 1). In general mean, maximum and 
minimum stock size showed a consistent seasonal variation (Table 1, Fig. 4). Nauplii were observed throughout the year with high numbers occurring from April to November $\left(145 \times 10^{3}\right.$ to $280 \times 10^{3}$ nauplii $\left.\mathrm{m}^{-2}\right)$. The stock decreased during late autumn and reached a low in January-February 2003. Similar to 2002, nauplii numbers had started to increase in March followed by the spring maximum in April-May 2003.

In contrast to the nauplii, only a single maximum was observed for the copepodite stages $\mathrm{C}_{1}$ to $\mathrm{C}_{5}$ in May $2002\left(162 \times 10^{3}\right.$ to $293 \times 10^{3}$ ind. $\left.\mathrm{m}^{-2}\right)$. While stages $\mathrm{C}_{1}$ to $\mathrm{C}_{3}$ increased from late April to early May, the stock
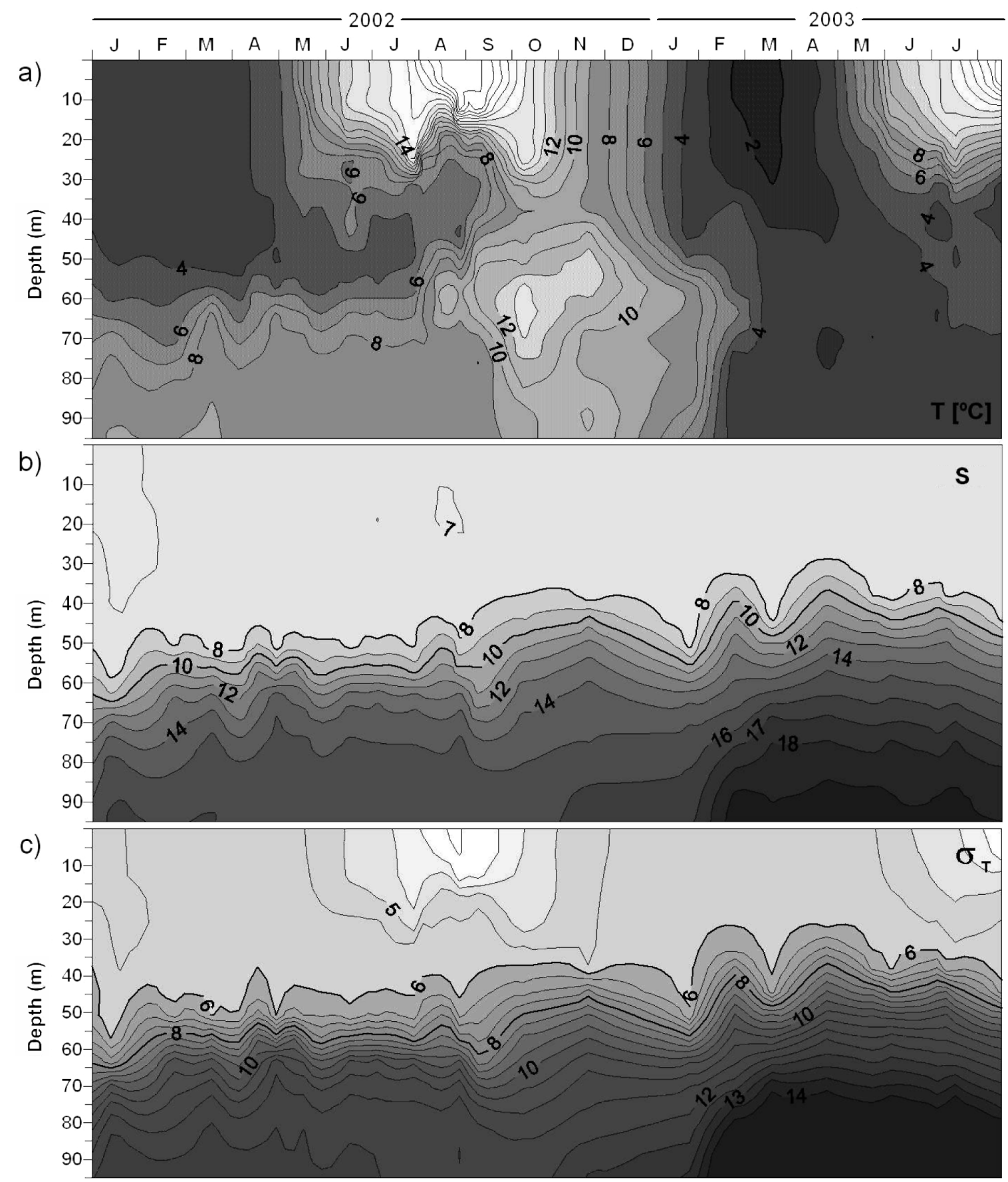

Fig. 2. Seasonal and vertical variation in (a) temperature $\left(T\right.$, in $\left.{ }^{\circ} \mathrm{C}\right)$, (b) salinity ( $\mathrm{S}$, measured on practical salinity scale) and (c) water density $\left(\sigma_{T}\right)$ at the central focus station in the Bornholm Basin during January 2002 to August 2003. Bold lines in (b) and (c) embrace the upper halocline or pycnocline ( $\mathrm{S}, 8$ to $10 ; \sigma_{T}, 6$ to 8 ) 
size of stages $\mathrm{C}_{4}$ and $\mathrm{C}_{5}$ rose from early May to late May. The stock of females and males increased also during May, but maxima of 148 to $314 \times 10^{3}$ ind. $\mathrm{m}^{-2}$ occurred later from June to August. From August to November, the stock of the copepodites and adults displayed little temporal variation and fluctuated from $20 \times 10^{3}$ to 60 $\times 10^{3}$ ind. $\mathrm{m}^{-2}$. During winter, $\mathrm{C}_{1}$ and $\mathrm{C}_{2}$ disappeared and $\mathrm{C}_{4}$ and $\mathrm{C}_{5}$ successively decreased, while females and males maintained a low stock of $6 \times 10^{3}$ to $10 \times 10^{3}$ ind. $\mathrm{m}^{-2}$. In spring 2003, only a small increase in the stock of copepodites was recorded from late April to late May, which was restricted to the younger stages $C_{1}$ to $C_{4}$. Moreover, the stock of all copepodites was 1 order of magnitude lower in May $2003\left(260 \times 10^{3}\right.$ ind. $\left.\mathrm{m}^{-2}\right)$ than in May $2002\left(1980 \times 10^{3}\right.$ ind. $\left.\mathrm{m}^{-2}\right)$ (Table 2, $\mathrm{C}_{\max }$ ).

The variation in stage composition emphasises the pronounced shift in the dominance from nauplii to a dominance of older stages that occurred in spring and in autumn to winter (Fig. 5). In spring 2002, the shift in the composition of the stock was confined to May, while the overwintering population showed a gradual shift from younger stages to $\mathrm{C}_{4}$ to $\mathrm{C}_{5}$ and adults from October to February. In spring 2003, again the succession from nauplii to copepodite dominance was observed. However, while the standing stock was composed of few nauplii $(11 \%)$ and $36 \%$ of late cope- podites $\left(\mathrm{C}_{4}\right.$ to $\left.\mathrm{C}_{6}\right)$ in late May 2002, young stages (nauplii, copepodite stages $C_{1}$ to $C_{3}$ ) made up more than $90 \%$ of the stock in late May 2003.

\section{Length and biomass}

The prosome length of the copepodite stages varied on a seasonal basis (Fig. 6). The largest copepodites were found in the period from March to May in both years. The length of all stages decreased from May to July and the minimum length occurred during July to August. It increased again in stages $C_{5}$ to $C_{6}$ during late summer to autumn and in $\mathrm{C}_{1}$ to $\mathrm{C}_{4}$ during winter. Mean prosome length showed significant differences between months for all stages (1-way ANOVA, p < 0.001). The pairwise multiple comparison, however, indicates that the prosome length increased or decreased gradually in most stages because length generally did not differ significantly from the preceding or succeeding sampling (Tukey's test, $\mathrm{p}>0.05$ ).

Total abundance and biomass showed a pronounced spring increase from $80 \times 10^{3}$ to $1300 \times 10^{3}$ ind. $\mathrm{m}^{-2}$ and from 0.08 to $2.21 \mathrm{~g} \mathrm{C} \mathrm{m}^{-2}$, respectively (Fig. 7). Due to

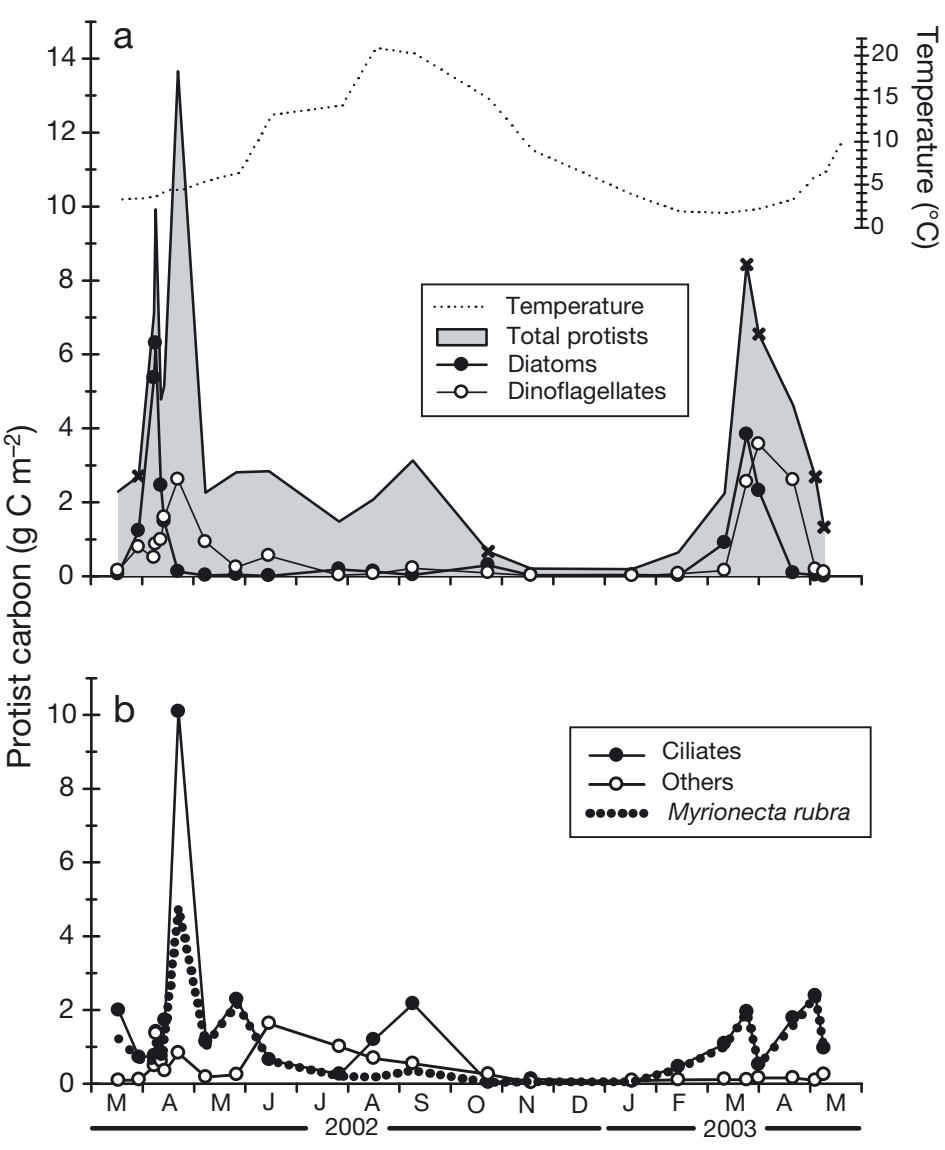

Fig. 3. Seasonal variation of the standing stock of (a) total protists, diatoms and dinoflagellates, and (b) ciliates and other protists ( $\mathrm{g} \mathrm{C}$ $\mathrm{m}^{-2}$ ) in the upper $30 \mathrm{~m}$ at the central station in the Bornholm Basin during March 2002 to May 2003. Crosses on top of the total protists biomass denote supplemented data from the HELCOM monitoring programme. Seasonal variation of the surface temperature at $10 \mathrm{~m}$ depth is shown in panel (a)

the clear succession from small nauplii to larger copepodites and adults, the increase in biomass occurred about 1 mo later than did the peak abundance. The second peak in abundance observed during October did not translate into an elevated biomass due to the dominance of small nauplii. Following the winter minimum, the increase in total abundance from March to April was similar in 2002 and 2003. However, no further increase was observed until the end of May 2003, and the biomass remained low.

\section{Vertical distribution and migration}

Nauplii and copepodites of Temora longicornis were distributed in the upper $60 \mathrm{~m}$ of the water column (Fig. 8a,b). The upper halocline appeared to limit the downward extension of the stock because organisms were rarely observed below isohalines with $\mathrm{S}$ of 


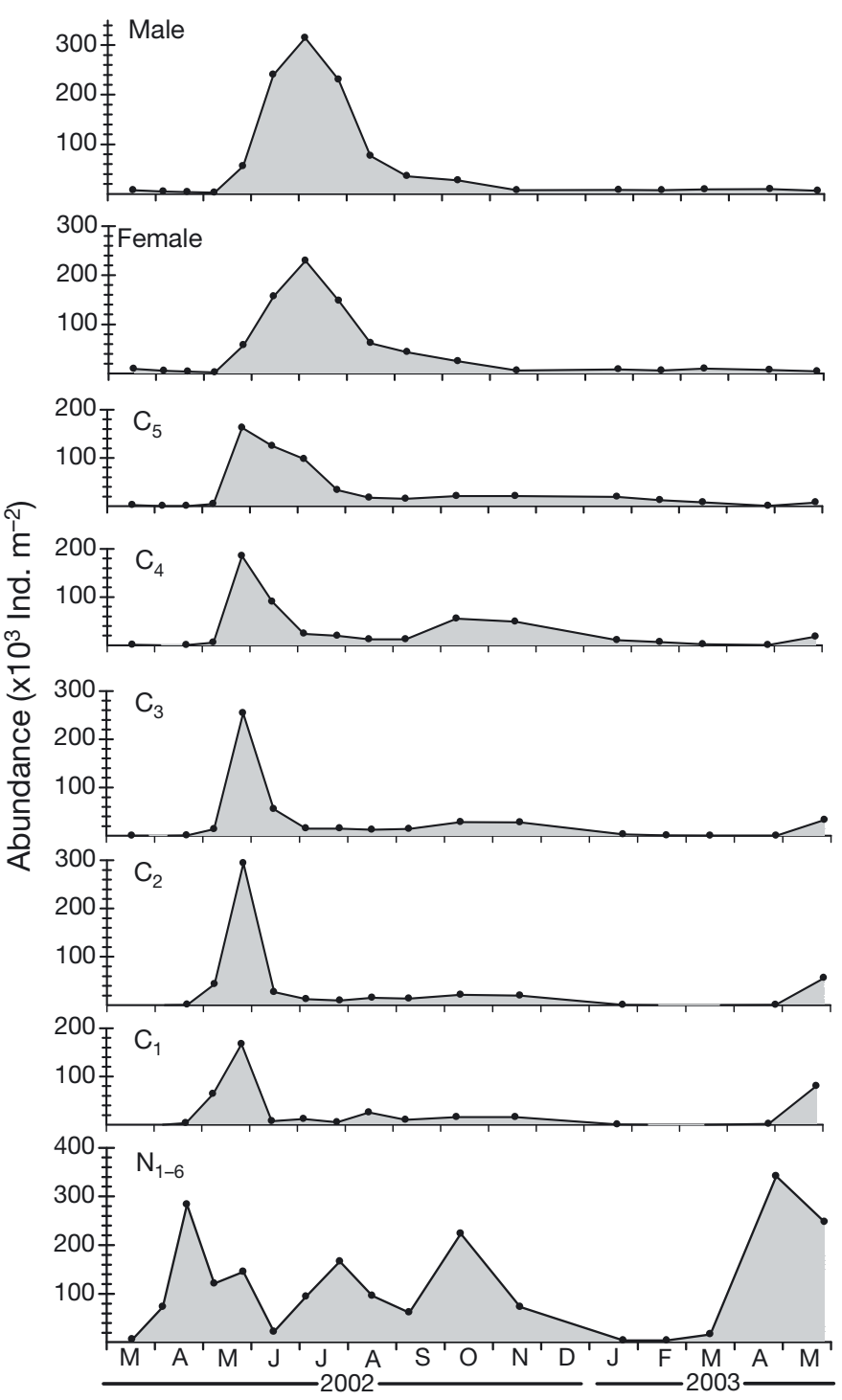

Fig. 4. Temora longicornis. Seasonal variation of the mean standing stock (no. ind. $\times 10^{3} \mathrm{~m}^{-2}$ ) of nauplii $\mathrm{N}_{1}$ to $\mathrm{N}_{6}$ (bottom panel), copepodite stages $\mathrm{C}_{1}$ to $\mathrm{C}_{5}$ (middle panels) and males and females (top panels) in the Bornholm Basin during March 2002 to May 2003

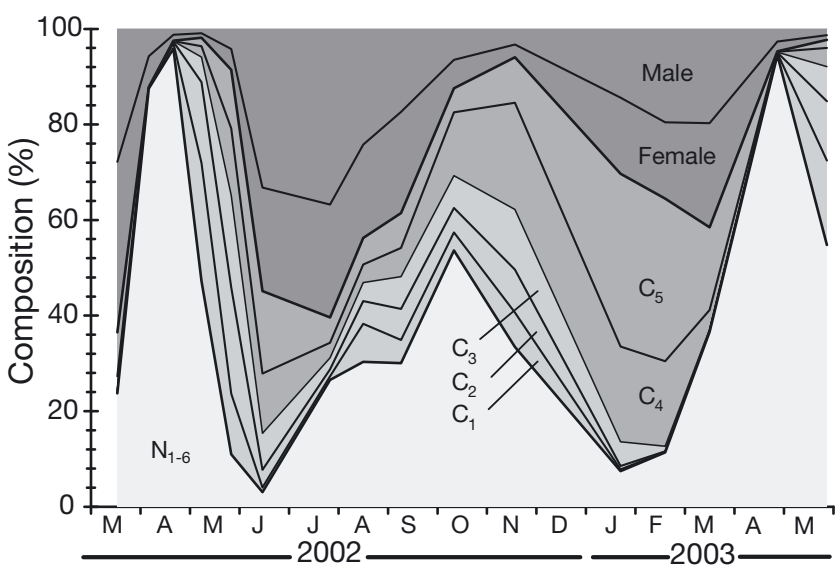

Fig. 5. Temora longicornis. Stage structure (\%) of the mean standing stock of $T$. longicornis in the Bornholm Basin during March 2002 to May 2003

10 to 12 . The weighted mean depth indicates that nauplii showed a shallow distribution, while the residence depth of copepodites during daytime increased with increasing stage. In spring, younger stages (nauplii and copepodites up to $\mathrm{C}_{4}$ ) occurred in the uppermost $20 \mathrm{~m}$ of the water column, but during June to August 2002 they were concentrated in narrow depth horizons below the thermocline at a depth of 20 to $50 \mathrm{~m} . \mathrm{C}_{5}$ females and males showed a similar shift from a shallow depth distribution in spring (0 to $40 \mathrm{~m}$ ) to a deeper vertical position during early summer (20 to $60 \mathrm{~m}$ ). From November 2002 onwards, all copepodite stages resumed the shallow vertical depth distribution (0 to $40 \mathrm{~m}$ ) displayed during spring. The strong cooling of the water column in March 2003 had no clear effect on the distribution of nauplii and copepodites. Diel vertical migration was observed for all stages except nauplii in the period from June to October when copepodites migrated from their deeper daytime position into the depth of 10 to $20 \mathrm{~m}$ (Fig. $8 \mathrm{a}, \mathrm{b})$. Only in July, there was no evidence for vertical migration.

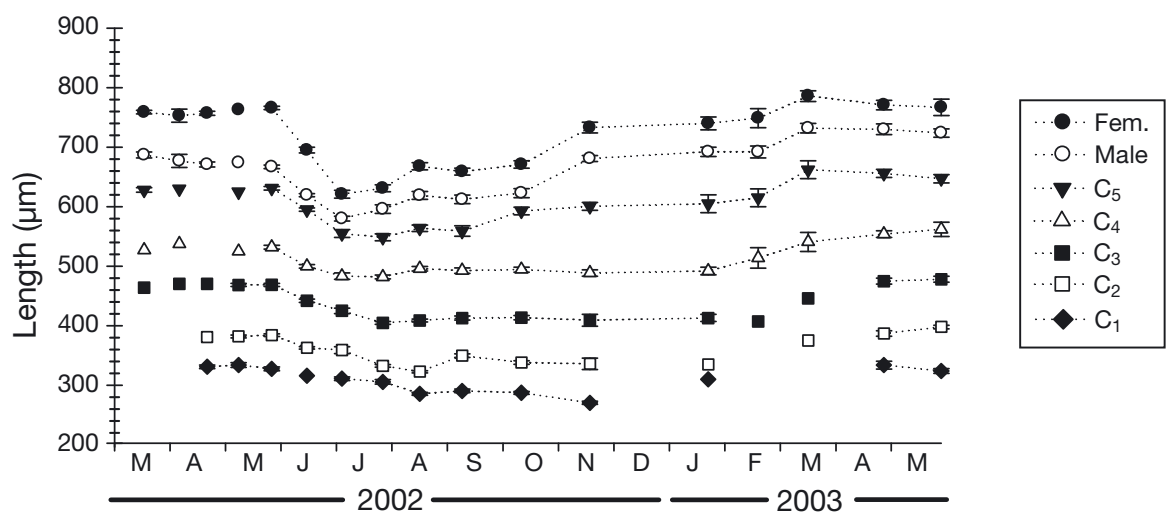

Fig. 6. Temora longicornis. Seasonal variation of prosome length $(\mu \mathrm{m} \pm 1 \mathrm{SE})$ of formalin preserved copepodite stages $\mathrm{C}_{1}$ to $\mathrm{C}_{5}$ and males and females of $T$. longicornis in the Bornholm Basin during March 2002 to May 2003. Symbols not connected to lines indicate periods when fewer than 30 individuals had been sized due to low abundance of that stage 

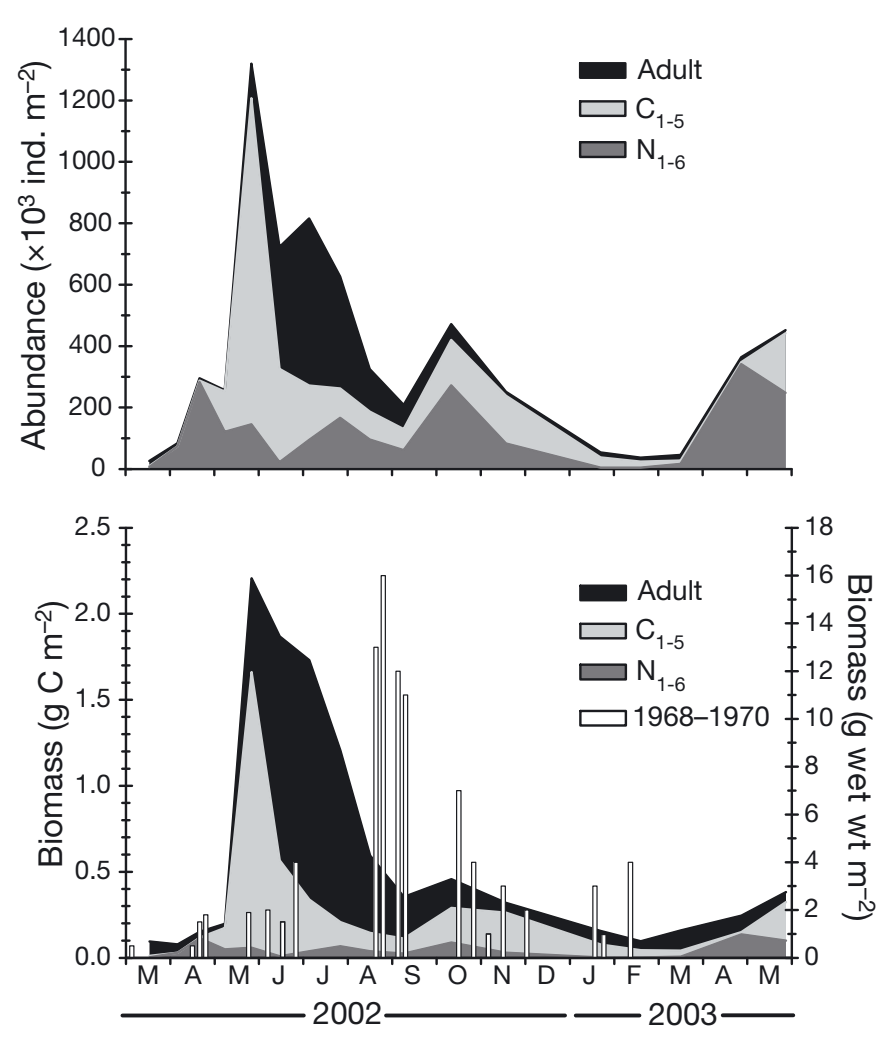

Fig. 7. Temora longicornis. Mean abundance (no. ind. $\times 10^{3} \mathrm{~m}^{-2}$, upper panel) and biomass ( $\mathrm{g} \mathrm{C} \mathrm{m}^{-2}$, lower panel) of nauplii $\left(\mathrm{N}_{1}\right.$ to $N_{6}$ ), copepodites $\left(C_{1}\right.$ to $C_{5}$ ) and adults (both males and females) in the Bornholm Basin during March 2002 to May 2003. Vertical bars show the mean biomass ( $g$ wet weight $\mathrm{m}^{-2}$ ) of the species for the period from 1968 to 1970 (redrawn from Hernroth \& Ackefors 1979)

\section{Life cycle}

The forward projection of cohort development suggests that Temora longicornis produces a maximum of 5 to 6 generations $\mathrm{yr}^{-1}$ (Fig. 9). Based on calculated stage durations, nauplii occurring in mid-March and early to mid-April matured from late May onwards until June (generation $\mathrm{G}_{1}$ ) and produced a new generation $\left(\mathrm{G}_{2}\right)$ that matured during July to August. Two more potential generations could be derived from nauplii occurring in July $\left(\mathrm{G}_{3}\right)$ and in August-September $\left(\mathrm{G}_{4}\right)$, respectively. The calculated generation time was shortest in $\mathrm{G}_{4}$ ( 1 to $1.5 \mathrm{mo}$ ) due to warm temperatures prevailing in September-October. In contrast, stage durations during winter were long, suggesting that the nauplii observed in October-November 2002 represented the start of the overwintering generation that would mature from February 2003 onwards. Theoretically, a 5th generation could have occurred from late September to November, but sampling intervals were too long to provide evidence for the presence of nauplii at the end of September.

\section{DISCUSSION}

Although Temora longicornis is a key species in the Baltic Sea, its life cycle and population dynamics are largely unknown. Earlier studies based on seasonally limited data described the principal variation in abundance or biomass with a winter minimum, spring increase and summer maximum (Hernroth \& Ackefors 1977, Möllmann et al. 2000), which is typical for coastal copepods in environments characterised by a large thermal amplitude (e.g. Colebrook 1985). After the hibernation period as copepodite stages $\mathrm{C}_{4}$ to $\mathrm{C}_{6}$, a shift in stage composition from nauplii and young copepodites to older copepodite stages from spring to summer has been observed (Hernroth \& Ackefors 1977, Möllmann et al. 2000). The seasonal development of $T$. longicornis in the Bornholm Basin during 2002-2003 follows this basic pattern, but the high resolution sampling reveals more details regarding overwintering, spring development of the population, number of generations per year and potential causes for variability in springtime increase in biomass in the Baltic Sea.

\section{Life cycle of Temora longicornis in the Bornholm Sea}

The life cycle of Temora longicornis was constructed from the observed occurrence of nauplii and the projected cohort development and forms the basis for the identification of important processes in the dynamics of the population that are sensitive to environmental forcing. This projection suggests that the species produced about 5 to 6 generations in 2002 . Some uncertainty in this scheme is associated with the biweekly to monthly sampling schedule. The onset of generations and magnitude of the peaks are imprecisely defined or could have been missed, particularly during the warmer part of the year, and need to be interpreted with caution. Uncertainty exists also in the applicability of the Bělehrádek's functions to the brackish environment as they were initially derived from observations in fully marine conditions. Potential costs associated with osmoregulation may affect copepod development (e.g. Goolish \& Burton 1989). However, calculated stage durations and projected development generally compared well with the observed change in stage composition of the winter and spring cohorts as discussed later. The effect of a reduced salinity on development is, thus, assumed to be minor and the hypothetical succession of generations match the life cycle of T. longicornis at least during the colder period of the year. Since $90 \%$ of the population was distributed in the brackish water layer with $\mathrm{S}<8$, the 


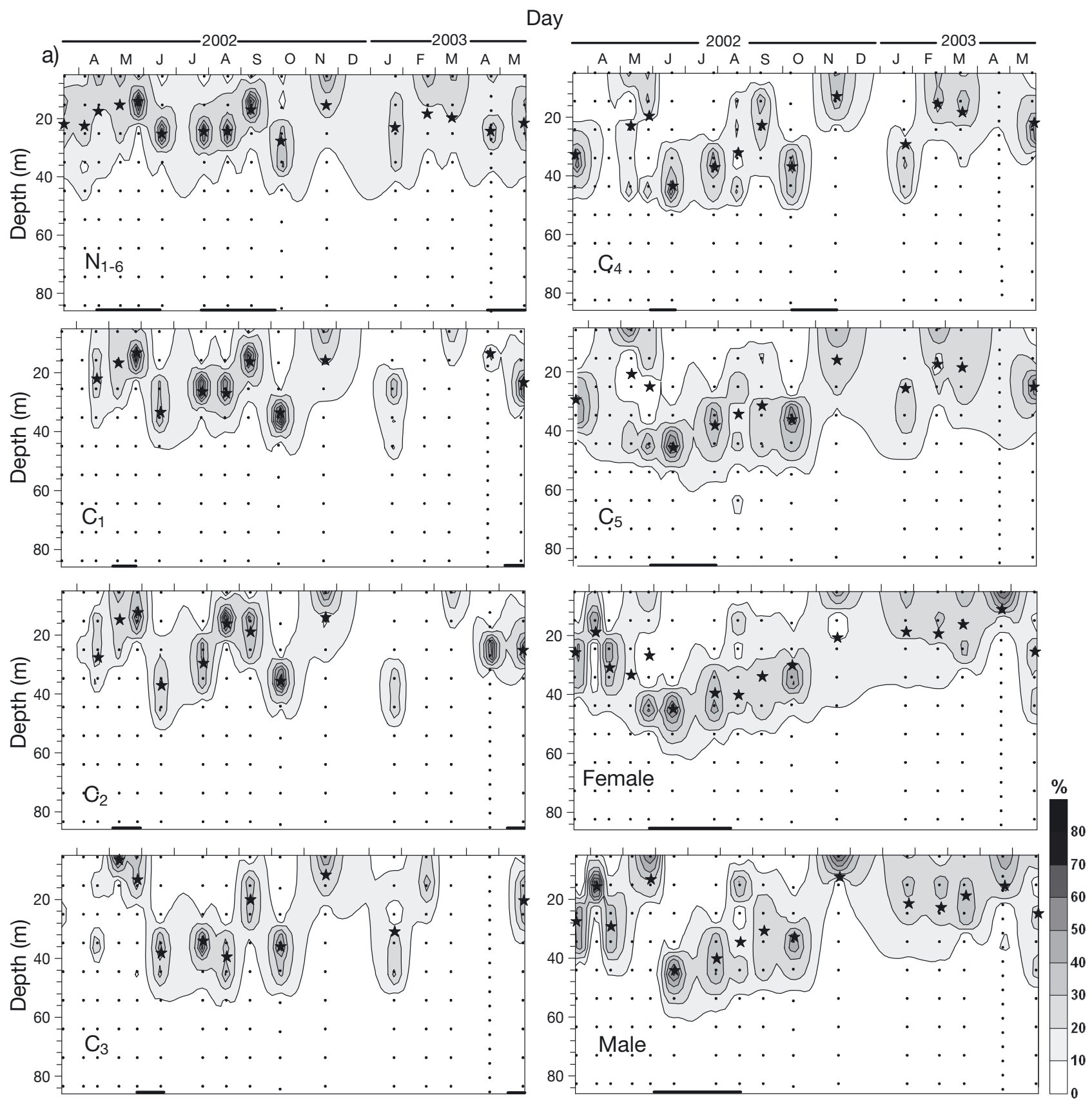

Fig. 8. Temora longicornis. Vertical distribution of nauplii $\mathrm{N}_{1}$ to $\mathrm{N}_{6}$, copepodite stages $\mathrm{C}_{1}$ to $\mathrm{C}_{5}$ and males and females in the Bornholm Basin during March 2002 to May 2003 shown as the contribution (\%) of the abundance at each depth to the total standing stock during (a) day and (b) night. Stars indicate the weighted mean depth for each stage, and dots give the mean depth of the vertical samples. Horizontal bars at the bottom of the figures indicate time of peak abundance of the stages according to Fig. 4

variation of temperature and food appear to be sufficient to construct the life cycle.

During winter and spring of 2002-2003, Temora longicornis overwintered as an active, but slowly developing population; there was no indication of a resting stage. This is reflected in the shift in stage composition from a dominance of nauplii and copepodite stages $C_{1}$ to $C_{3}$ in November to a dominance of $C_{4}$ to $C_{6}$ in January to early March (Fig. 5). The shift was associated with a strong reduction in nauplii stock and the nearly complete disappearance of stages $\mathrm{C}_{1}$ to $\mathrm{C}_{3}$ and $\mathrm{C}_{4}$ and $\mathrm{C}_{5}$ in February and March-April, respectively, while the abundance of adults maintained a low but constant level during winter and early spring (Fig. 4). 


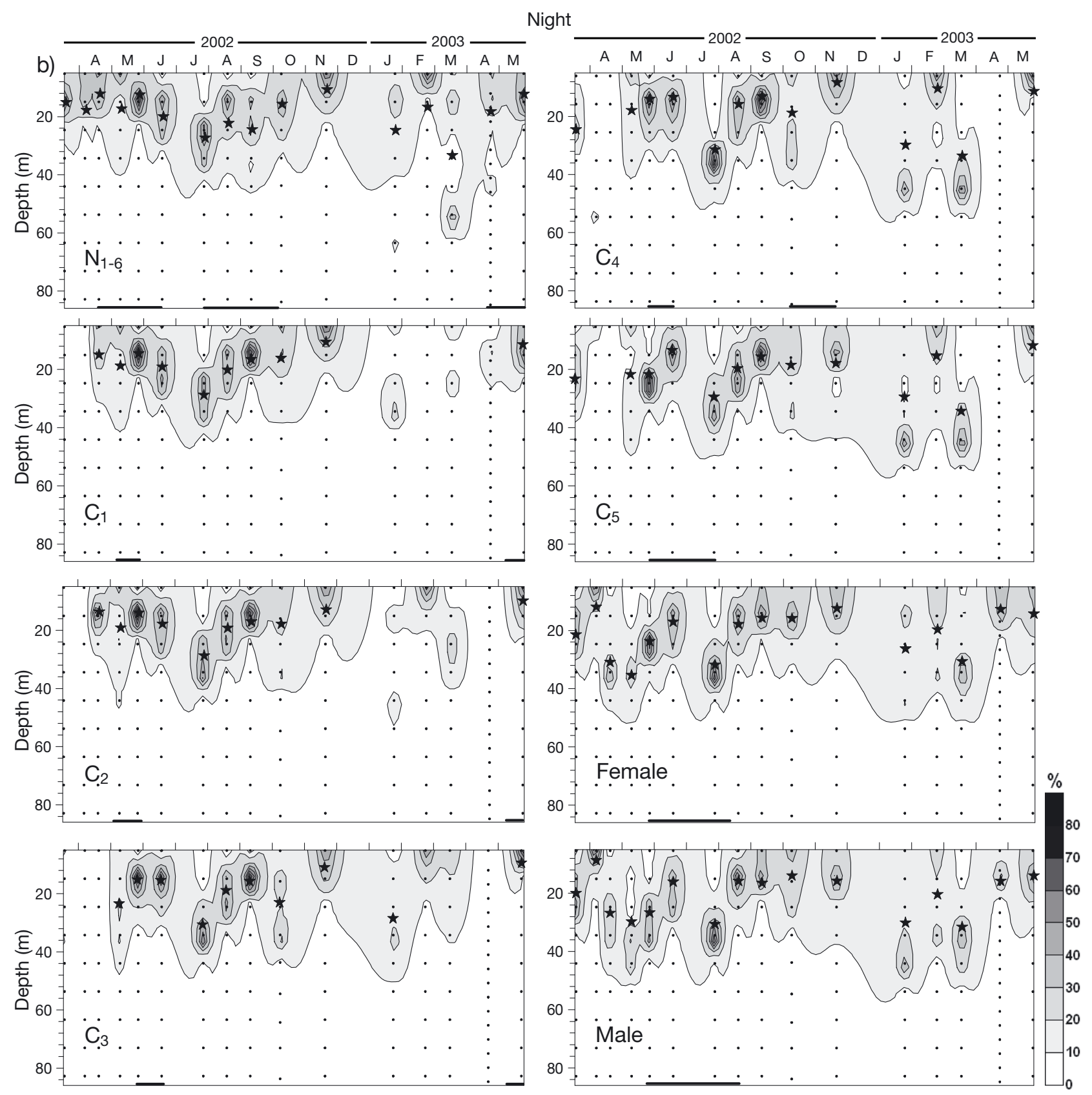

Fig. 8 (continued)

The increase in the size of $\mathrm{C}_{4}$ to $\mathrm{C}_{6}$ stages during January to March also marks the active development of an overwintering generation at low temperatures that replaced the smaller survivors of late autumn (Fig. 6). Due to unfavourable food concentrations $(<26.8 \mu \mathrm{g} \mathrm{C}$ $\left.\mathrm{l}^{-1}\right)$ and low temperatures $\left(<3.7^{\circ} \mathrm{C}\right)$ during winter, estimated stage durations were long (6 to $20 \mathrm{~d}$, Table 2). This suggests that the large, new females observed in March originated from spawning in the period October-November $\left(G_{5}\right.$ and $G_{6}$, Fig. 9).
Following the winter minimum, the nauplii increased from March to the end of April when they dominated the standing stock by more than $90 \%$ in both 2002 and 2003. This increase coincided with the increase of food availability during the spring bloom, which suggests that in situ egg production by the recently matured females of the overwintering generation was the most likely origin of nauplii. The pronounced peak of nauplii in April gave rise to the development of the spring generation indicated by the 


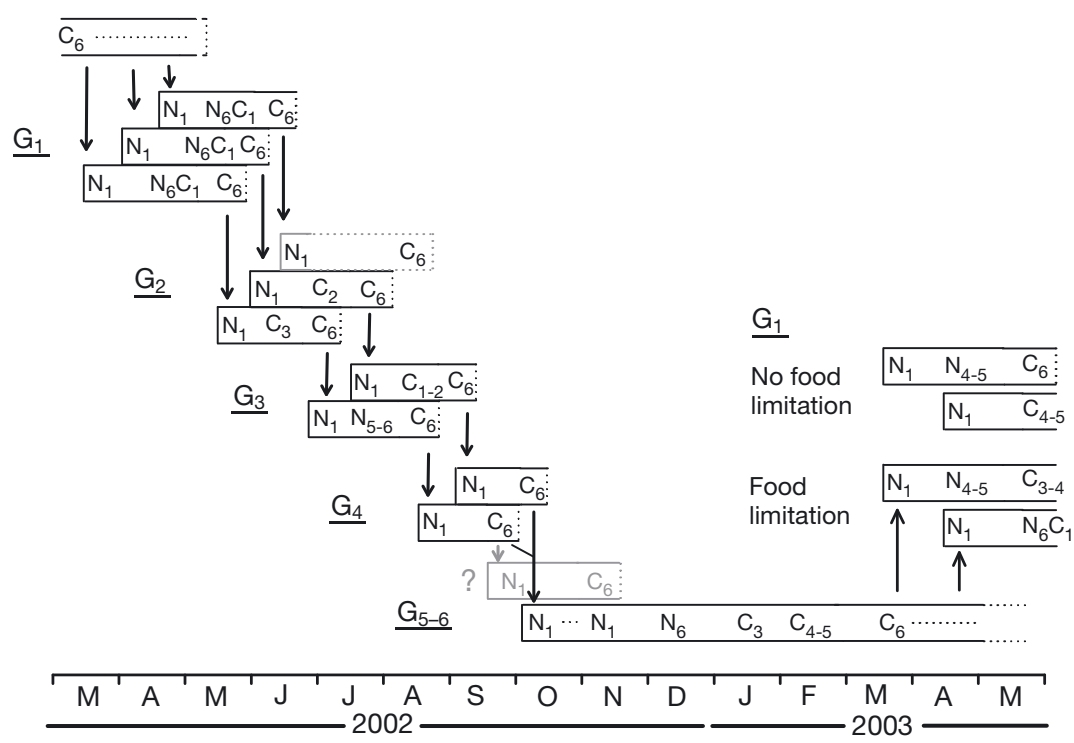

Fig. 9. Temora longicornis. Hypothetical life history indicating different generations/cohorts in the Bornholm Basin during March 2002 to May 2003 based on stage durations given in Table 2. For the first generation in $2003\left(\mathrm{G}_{1}\right)$, the development of the cohorts is shown for food saturation and for food limitation starting at the beginning of May. For further explanations see 'Discussion: Life cycle of Temora longicornis in the Bornholm Sea' occurrence of stages $\mathrm{C}_{1}$ to $\mathrm{C}_{3}$ in May and $\mathrm{C}_{4}$ in May-June and the broader seasonal maxima of $\mathrm{C}_{5}$ females and males during June to July 2002 (Fig. 4). Calculated stage durations and length data suggest that this observed succession of stages from April to July does not merely represent the development of a single spring generation as indicated by the shift in stage composition from a dominance of nauplii to adults (Fig. 5). Instead, a succession of generations $\left(\mathrm{G}_{1}\right.$ to $\mathrm{G}_{3}$ ) occurred within the observed peaks.

Females of the overwintering generation persisted approximately from March until early May when they disappeared as a result of lacking recruitment from the vanished copepodite pool (Fig. 4). This gives a relatively long period for the recruitment of the next generation $\left(\mathrm{G}_{1}\right)$ of more than 4 wk (Fig. 9). In 2002, food concentrations (70 to $300 \mu \mathrm{g} \mathrm{C} \mathrm{l}^{-1}$ ) appeared sufficient for optimal development until mid-June, but the low temperatures prevailing from March to early May (3.3 to $5.5^{\circ} \mathrm{C}$ ) probably caused long stage durations of 4 to $7 \mathrm{~d}$ stage $^{-1}$ particularly for the early offspring (Table 2 ). The forward projection suggests that the early nauplii of $\mathrm{G}_{1}$ were spawned in late March and moulted to $\mathrm{C}_{1}$ during mid-April and to adults at the end of May (Fig. 9). This compares well with the appearance of new $C_{1}$ to $C_{3}$ stages of larger size at the end of April and of new adults at the end of May in the field (Figs. 4 \& 5). Similarly, the nauplii of $\mathrm{G}_{1}$ spawned in early and late April were calculated to moult to adults during early to mid-June, which is again well reflected by the sequence of peaks of nauplii and stages $C_{1}$ to $C_{5}$ at the end of April and the end of May, respectively, and the large increase in adult abundance from May to June in the field (compare Figs. $4 \& 9$ ). The strong decrease in the size of females in June, in contrast, suggests the arrival of females of the next generation $\left(\mathrm{G}_{2}\right)$. Signifi- cant differences in length of adults, which during development are related to food abundance and, inversely, temperature, are generally used to separate different generations of Temora longicornis (Evans 1977). However, calculated stage durations of about 3 $\mathrm{d}_{\text {stage }} \mathrm{s}^{-1}$ during late May-June appear generally too long for nauplii spawned by early females of $\mathrm{G}_{1}$ in late May to develop into adulthood by mid-June. Thus, the females collected in June probably originated from nauplii of $\mathrm{G}_{1}$ spawned in April that developed from $\mathrm{N}_{6}$ or $\mathrm{C}_{1}$ onwards at increasing water temperatures during May $\left(5.5\right.$ to $\left.9.4^{\circ} \mathrm{C}\right)$. They were, therefore, smaller than the individuals spawned in late March, which developed at lower temperatures (Fig. 9, Table 2). The offspring spawned by $\mathrm{G}_{1}$ in May-June reached adulthood from the end of June onwards as indicated by the further decrease in size (Figs. $5 \&$ 9, Table 2). In the field samples, generation $\mathrm{G}_{2}$ occurred as a small nauplii peak at the end of May and as elevated concentrations of $\mathrm{C}_{4}$ to $\mathrm{C}_{6}$ during June and the beginning of July, while stages $C_{1}$ to $C_{3}$ have apparently been missed (Fig. 4). The minimum nauplii abundance in June coincided with a high abundance of $\mathrm{C}_{5}$ and $\mathrm{C}_{6}$ and, therefore, might be caused by food limitation and cannibalism (e.g. Daan et al. 1988, Peterson \& Kimmerer 1994). These nauplii potentially did not survive to adults.

As discussed above, the environmental conditions and the development of $\mathrm{G}_{2}$ and subsequent generations in the field are difficult to assess because in the monthly sampling intervals after July the water column got warmer. In addition, cyanobacteria dominated the seston composition among the group of 'others' during June to August and their contribution to the copepod diet and development is uncertain (e.g. Meyer-Harms et al. 1999). While the temperatures changed only little due to the submergence of the pop- 
ulation below the thermocline from June to September, the food concentration was variable and did not exceed $50 \mu \mathrm{g} \mathrm{C}^{-1}$ during July and could have limited copepod development (Table 2). Calculated stage durations were, therefore, long during this period (5 to $7 \mathrm{~d}_{\text {stage }} \mathrm{s}^{-1}$ ) and suggest that the females observed at the end of July still belonged to $G_{2}$. This observation is supported by their small size, similar to that of females occurring at the beginning of July (Fig. 5).

Although the stock of nauplii remained high during the second half of the year with further peaks at the end of July and during October, the stocks of stages $\mathrm{C}_{1}$ to $\mathrm{C}_{6}$ were generally low. The calculated stage durations suggest that another four overlapping generations could have followed: $\mathrm{G}_{3}$ from July to early September, $\mathrm{G}_{4}$ from late August to early October, $\mathrm{G}_{5}$ from late September to early November and the overwintering generation $\mathrm{G}_{6}$ from October or November onwards (Fig. 9). Stage durations of these hypothetical generations probably depended on the food availability, which was variable from August to November, while the environmental temperatures experienced by Temora longicornis were always in the range optimal for fast development and high survival (e.g. Klein Breteler \& Gonzales 1986). The increase in the size of $\mathrm{C}_{5}$ to $\mathrm{C}_{6}$ from the minimum observed in July-August to that in November reflects the increase in food availability during the period of August to October and decreasing water temperatures following mid-October (Table 2).

\section{Comparison with the life cycle of Temora longicornis in other areas}

The life cycle of Temora longicornis in the Bornholm Basin principally resembles the few earlier descriptions of this species in marine environments such as the North Sea and Long Island Sound (e.g. Marshall 1949, Deevey 1956, Evans 1977, Peterson 1985). Most investigations suggest that $T$. longicornis - similar to our observation in the Baltic-overwinters in low abundance as an active population (Evans 1977, Hay et al. 1991, Wesche et al. 2007). The stage composition of the overwintering stock varied widely from a dominance of nauplii and copepodites (Marshall 1949, Evans 1977, Wesche et al. 2007) to a dominance of older copepodites or adults (Digby 1950, the present study). This variability might reflect the availability of food during winter. Hay et al. (1991) observed a higher biomass and winter reproduction of $T$. longicornis related to higher chlorophyll a levels in the southeastern region of the North Sea compared with the northwestern region. In the Bornholm Basin, food levels are too low to enable a continuous winter reproduction like that in the North Sea, but still are sufficient to allow the slow development of a winter generation.

The increase in nauplii abundance in spring and the onset of population development is generally related to a burst in egg production by females in response to phytoplankton blooms (Evans 1977, Bakker \& van Rijswijk 1987, Peterson \& Kimmerer 1994). However, Temora longicornis is also known to produce resting eggs that hibernate in the sediment (Lindley 1990, Castellani \& Lucas 2003). The early occurrence of nauplii in spring, therefore, has been attributed to the hatching of resting eggs (Marshall 1949, Bakker \& van Rijswijk 1987), but their contribution to spring recruitment is poorly known. In the western Baltic Sea, evidence for resting egg production of $T$. longicornis is lacking (Madhupratap et al. 1996, J. Dutz unpubl. data), which suggests that the first generation is initiated by the egg production of overwintering females in response to the spring phytoplankton bloom.

While the population development is initiated through bursts in egg production triggered by the spring bloom (Evans 1977, Peterson \& Kimmerer 1994), the spring biomass increase of the population is associated with the occurrence of larger copepodite stages (Fig. 7) and, thus, controlled by the temperature-dependent development rate of the offspring. Temora longicornis is adapted to temperate environments and stage durations increase strongly at temperatures $<5$ to $7^{\circ} \mathrm{C}$ (Corkett \& McLaren 1970, Klein Breteler \& Gonzales 1986). Therefore, timing of the spring bloom and the environmental temperatures during development are important for the timing of the biomass maximum of $T$. longicornis. In the North Sea, the spring bloom occurs at mild temperatures; due to moderate stage durations at 6 to $12^{\circ} \mathrm{C}$ generation times are short $(<40$ d) and the timing of the biomass maximum is related to the timing of the temporally variable spring bloom (see Marshall 1949, Bakker \& van Rijswijkj 1987). The spring bloom in the Baltic Sea or in Long Island Sound, however, occurs at low temperatures $\left(<2\right.$ to $\left.4^{\circ} \mathrm{C}\right)$ at which development rates and generation times are long (>59 d). The biomass increase is delayed until the warming of the water column occurs (Peterson 1985, the present study).

The number of subsequent generations produced by Temora longicornis is variable and apparently also controlled by the environmental temperatures. In the shallow Long Island Sound and the Oosterschelde Estuary, which exhibit large amplitudes in the seawater temperature of 0 to $>20^{\circ} \mathrm{C}$, generally not more than 2 to 3 generations were reported; the species disappeared in summer when the temperature exceeded $17^{\circ} \mathrm{C}$ (Peterson 1985, Bakker \& van Rijswijk 1987, Peterson \& Kimmerer 1994). In contrast, 4 to 6 generations were observed in areas characterised by small 
temperature amplitudes and maxima rarely exceeding $17^{\circ} \mathrm{C}$, such as the Clyde Sea at Loch Striven, the English Channel or coastal waters off Northumberland (Digby 1950, Evans 1977, McLaren 1978). Although the surface temperatures in the Bornholm Basin also showed a large seasonal variation that exceeded $20^{\circ} \mathrm{C}$ during summer, T. longicornis produced 5 to 6 generations in 2002. This can be largely attributed to the vertical thermal structure of the water column. Following the onset of seasonal stratification, $T$. longicornis submerged into the cooler intermediate water during summer and experienced a low temperature range of 3.8 to $13.8^{\circ} \mathrm{C}$, which allowed the species to persist throughout the year (Figs. 1 \& 8). In autumn, secondary maxima in stock and biomass were observed, which are characteristic for T. longicornis in areas with 4 to 6 generations (e.g. Digby 1950). They were mostly visible in nauplii or in copepodite stage $\mathrm{C}_{4}$, and could have been missed in the other stages due to the monthly sampling schedule. Predation might also have been important in limiting the peaks in abundance.

\section{Variable spring timing of Temora longicornis}

Our study showed a pronounced difference in the early spring development of the first generation between the years 2002 and 2003. In May 2003, the total biomass was low and the stage composition of the stock indicated a retarded population development. Nauplii still dominated the population structure, the stock size of copepodites was small and new females of $\mathrm{G}_{1}$ were not present yet, in contrast to the mature population structure in May 2002.

The timing of the spring bloom as a trigger for reproduction and the environmental temperatures during development are both important factors that determine the timing of the spring cohort in Temora longicornis. One would, therefore, suspect that the cold winter and spring conditions during 2003, with a minimum of $1.7^{\circ} \mathrm{C}$ in March, caused the retarded population development in comparison with winter to spring 2002 when temperatures did not fall $<3.3^{\circ} \mathrm{C}$. Such low temperatures are expected to delay the thermal stabilisation of the brackish water column and the vernal phytoplankton bloom in the Bornholm Basin (Wasmund et al. 1998), and, thus, would also affect the onset of reproduction in T. longicornis. In addition, stage durations of the offspring are strongly prolonged by small decreases in temperatures (Corkett \& McLaren 1970).

A delay in the timing of the spring bloom and in the onset of reproduction, however, did not become apparent in our data. The spring bloom had already occurred by the end of March and slightly earlier than during the warmer winter of 2002. The shift in stage composi- tion from adults to nauplii occurred accordingly in March-April and indicated a similar timing of reproduction as that in 2002. The calculated stage durations suggest that the development of nauplii was delayed at the end of April $\left(\mathrm{N}_{4}\right.$ to $\mathrm{N}_{5}$ in 2003 versus $\mathrm{N}_{6}$ to $\mathrm{C}_{1}$ in 2002; Fig. 9). However, the rapid spring warming of the water column to $9.4^{\circ} \mathrm{C}$ until the end May 2003 $\left(8.4^{\circ} \mathrm{C}\right.$ in 2002$)$ should have favoured a fast population development. Assuming food saturation, the March cohort should, therefore, have matured to adulthood by the end of May, while the April cohort was projected to develop to $C_{4}$ and $C_{5}$ (see Fig. 9). The slow development, however, can be explained when food limitation during May is taken into account. The March and April cohorts were then calculated to develop to $\mathrm{C}_{3}$ and $\mathrm{C}_{4}$ and to $\mathrm{N}_{6}$ and $\mathrm{C}_{1}$, respectively, which meets the stage composition of Temora longicornis observed in the field (Fig. 9). Food limitation could have been created by the early spring bloom, which presumably was induced by the shallow mixing depth following the inflows of saline water during autumn to winter and the earlier onset of the food-limited period typically following the spring bloom (e.g. Peterson1985, Klein Breteler \& Gonzales 1986, the present study). Unfortunately, estimates of food abundance were not available for late May. However, the food concentration in early May 2003 was already lower than in 2002 and the protist community consisted entirely of Myrionecta rubra, which is captured inefficiently by T. longicornis (Jakobsen et al. 2002). Thus, food limitation was not unlikely and explains prolonged stage durations and the retarded population development observed in spring 2003.

The analysis of the life cycle and stock dynamics of Temora longicornis in the Bornholm Basin shows that the timing of the spring biomass increase is associated with the maturation of the first generation. The timing can be variable and delayed when the prevailing environmental conditions during the cohort development from March to May are unfavourable. Data provided by Hernroth \& Ackefors (1978) on the biomass variation of $T$. longicornis in the Bornholm Sea from 1968 to 1970 supports a strong variability in spring timing of the species (Fig. 7). In comparison with 2002-2003, Hernroth \& Ackefors (1977) recorded the spring increase and the biomass maximum from the end of June to August-September, which is approximately 1 to 2 mo later than during the present study. Our analysis suggests that the spring development of $T$. longicornis is complex and depends not only on the winter to spring temperatures, but also on the spring bloom timing and food availability during the post bloom phase. The interactions of these factors and their implications for the species' spring timing are not yet completely understood and require further study. Nevertheless, the apparently strong variabil- 
ity has important implications for the current interpretation of long-term changes in the Baltic Sea, which are at present inferred from coarsely resolved monitoring in February, May, August and November. The increasing trend in the biomass of the species during the last 2 decades is interpreted as a numerical response of the population to the warming of the surface water layers (e.g. Alheit et al. 2005). However, it could also reflect the earlier timing in the population development. Thus, it remains to be investigated to what extent the observed long-term changes are based on the earlier occurrence of a similar population size or whether they reflect an overall increase in population number.

Acknowledgements. The study was funded by the German Federal Ministry for Education and Research within the GLOBEC GERMANY project (03F0418C). We are grateful to N. Wasmund (Institute for Baltic Sea Research, Germany) for providing valuable HELCOM data on the standing stock of phytoplankton. We thank the crews and scientific parties of the RV 'Heincke', RV 'Alkor' and RV 'Alexander von Humboldt" for excellent support during the study.

\section{LITERATURE CITED}

Alheit J, Möllmann C, Dutz J, Kornilovs G, Loewe P, Mohrholz V, Wasmund N (2005) Synchronous ecological regime shifts in the central Baltic and the North Sea in the late 1980s. ICES J Mar Sci 62:1205-1215

Bakker C, van Rijswijk P (1987) Development time and growth rate of the marine calanoid copepod Temora longicornis as related to food conditions in the Oosterschelde estuary (Southern North Sea). Neth J Sea Res 21:125-141

Beaugrand G, Reid P, Ibañez F, Lindley JA, Edwards M (2002) Reorganization of North Atlantic marine copepod biodiversity and climate. Science 296:1692-1694

Bollens SM, Frost BW (1989) Predator-induced diel vertical migration in a planktonic copepod. J Plankton Res 11:1047-1065

Casini M, Cardinale M, Arrhenius F (2004) Feeding preferences of herring (Clupea harengus) and sprat (Sprattus sprattus) in the southern Baltic Sea. ICES J Mar Sci 61:1267-1277

> Casini M, Hjelm J, Molinero JC, Lövren J and others (2009) Trophic cascades promote threshold-like shifts in pelagic marine ecosystems. Proc Natl Acad Sci USA 106:197-202

Castellani C, Lucas IAN (2003) Seasonal variation in egg morphology and hatching success in the calanoid copepods Temora longicornis, Acartia clausi and Centropages hamatus. J Plankton Res 25:527-537

Colebrook JM (1985) Continuous plankton records: overwintering and annual fluctuations in the abundance of zooplankton. Mar Biol 84:261-265

Corkett CJ, McLaren IA (1970) Relationship between development rate of eggs and older stages of copepods. J Mar Biol Assoc UK 50:161-168

CPR (Continuous Plankton Recorder) Survey Team (2004) Continuous plankton records: plankton atlas of the North Atlantic Ocean (1958-1999). II. Biogeographical charts. Mar Ecol Prog Ser (Suppl 2004):11-75

> Daan R, Gonzales S, Klein Breteler WCM (1988) Cannibalism in omnivorous calanoid copepods. Mar Ecol Prog Ser 47: $45-54$
Deevey GB (1956) Oceanography of Long Island Sound, 19521954. V. Zooplankton. Bull Bingham Oceanogr Coll 15: 113-155

Digby PSB (1950) The biology of the small planktonic copepods of Plymouth. J Mar Biol Assoc UK 29:393-438

> Dippner JW, Kornilovs G, Sidrevics L (2000) Long-term variability of zooplankton in the Central Baltic Sea. J Mar Syst 25:23-31

Dippner JW, Vuorinen I, Daunys D, Flinkman J and others (2008) Climate related ecosystem change. In: The BACC author team (eds) Assessment of climate change for the Baltic Sea basin. Springer, Berlin, p 309-378

Edler L (1979) Recommendations on methods for marine biological studies in the Baltic Sea. Phytoplankton and chlorophyll. Baltic Mar Biol Publ 5:1-38

Evans F (1977) Seasonal density and production estimates of the commoner planktonic copepods of Northumberland coastal waters. Estuar Coast Shelf Sci 5:223-241

Feistel R, Nausch G, Matthäus W, Hagen E (2003) Temporal and spatial evolution of the Baltic deep water renewal in spring 2003. Oceanologia 45:623-642

Flinkman J, Aro E, Vuorinen I, Viitasalo M (1998) Changes in the northern Baltic zooplankton and herring nutrition from 1980s to 1990s: top-down and bottom-up processes at work. Mar Ecol Prog Ser 165:127-136

Goolish EM, Burton RS (1989) Energetics of osmoregulation in an intertidal copepod: effects of anoxia and lipid reserves on the pattern of free amino accumulation. Funct Ecol 3:81-89

Hänninen J, Vuorinen I, Hjelt P (2000) Climatic factors in the Atlantic control the oceanographic and ecological changes in the Baltic Sea. Limnol Oceanogr 45:703-710

Hänninen J, Vuorinen I, Hjelt P (2003) Atlantic climatic factors control decadal dynamics of a Baltic Sea copepod Temora longicornis. Ecography 26:672-678

> Hansen FC, Möllmann C, Schütz U, Neumann T (2006) Spatio-temporal distribution and production of calanoid copepods in the central Baltic Sea. J Plankton Res 28:39-54

> Harris RP, Paffenhöfer GA (1976) Feeding, growth and reproduction of the marine planktonic copepod Temora longicornis Müller. J Mar Biol Assoc UK 56:675-690

Hay SJ, Kiørboe T, Matthews A (1991) Zooplankton biomass and production in the North Sea during the Autumn Circulation Experiment, October 1987-March 1988. Cont Shelf Res 11:1453-1476

Hernroth L, Ackefors H (1977) The zooplankton of the Baltic Proper. A long-term investigation of the fauna, its biology and ecology. Inst Mar Res Lysekil, Ser Biol, Rep 26:1-58

Jakobsen HH (2002) Escape of protists in predator-generated feeding currents. Aquat Microb Ecol 26:271-281

Klein Breteler WCM, Gonzales S (1986) Culture and development of Temora longicornis (Copepoda, Calanoida) at different conditions of temperature and food. Syllogeus 58:71-84

Köster P (2003) Körpermaße und Kohlenstoffgehalte dominanter Zooplanktonarten der Ostsee in Abhängigkeit von Salzgehalt, Ernährungszustand und Temperatur. MS thesis, University of Rostock

Lindley JA (1990) Distribution of overwintering calanoid copepod eggs in sea-bed sediments around southern Britain. Mar Biol 104:209-217

- MacKenzie B, Gislason H, Möllmann C, Köster FW (2007) Impact of 21st century climate change on the Baltic Sea fish community and fisheries. Glob Change Biol 13: 1348-1367

> Madhupratap M, Nehring S, Lenz J (1996) Resting eggs of zooplankton (Copepoda and Cladocera) from the Kiel Bay 
and adjacent waters (southwestern Baltic). Mar Biol 125: 77-87

Marshall SM (1949) On the biology of the small copepods in Loch Striven. J Mar Biol Assoc UK 28:45-122

McLaren IA (1978) Generation lengths of some temperate marine copepods: estimation, prediction, and implications. J Fish Res Board Can 35:1330-1342

Meyer-Harms B, Reckermann M, Voss M, Siegmund H, von Bodungen B (1999) Food selection by calanoid copepods in the euphotic layer of the Gotland Sea (Baltic Proper) during mass occurrence of $\mathrm{N}_{2}$-fixing cyanobacteria. Mar Ecol Prog Ser 191:243-250

Mohrholz V, Dutz J, Kraus G (2006) The impact of exceptionally warm summer inflow events on the environmental conditions in the Bornholm Basin. J Mar Syst 60:285-301

Möllmann C, Köster FW (2002) Population dynamics of calanoid copepods and the implications of their predation by clupeid fish in the Central Baltic Sea. J Plankton Res 24:959-977

Möllmann C, Kornilovs G, Sidrevics L (2000) Long-term dynamics of main mesozooplankton species in the central Baltic Sea. J Plankton Res 22:2015-2038

Möllmann C, Köster FW, Kornilovs G, Sidrevics L (2003) Interannual variability in population dynamics of calanoid copepods in the Central Baltic Sea. ICES Mar Sci Symp 219:220-230

Ojaveer E, Lumberg A, Ojaveer H (1998) Highlights of zooplankton dynamics in Estonian waters (Baltic Sea). ICES J Mar Sci 55:748-755

Peterson B, Kimmerer W (1994) Processes controlling recruitment of the marine calanoid copepod Temora longicornis in Long Island Sound: egg production, egg mortality and cohort survival rates. Limnol Oceanogr 39:1594-1605

Editorial responsibility: William Peterson,

Newport, Oregon, USA
Peterson WT (1985) Abundance, age structure and in situ egg production rates of the copepod Temora longicornis in Long Island Sound, New York. Bull Mar Sci 37:726-738

Putt M, Stoecker DK (1989) An experimentally determined carbon:volume ratio for marine 'oligotrichous' ciliates from estuarine and coastal waters. Limnol Oceanogr 34: 1097-1103

Richardson AJ (2008) In hot water: zooplankton and climate change. ICES J Mar Sci 65:279-295

Utermöhl H (1958) Zur Vervollkommnung der qualitativen Phytoplankton-Methodik. Mitt Int Ver Theor Angew Limnol 9:1-38

Viitasalo M, Vuorinen I, Saesmaa S (1995) Mesozooplankton dynamics in the northern Baltic Sea: implications of variations in hydrography and climate. J Plankton Res 17:1857-1878

Vuorinen I, Hänninen J, Viitasalo M, Helminen U, Kuosa H (1998) Proportion of copepod biomass declines with decreasing salinity in the Baltic Sea. ICES J Mar Sci 55:767-774

Vuorinen I, Hänninen J, Kornilovs G (2003) Transfer-function modelling between environmental variation and mesozooplankton in the Baltic Sea. Prog Oceanogr 59:339-356

Wasmund N, Nausch G, Matthäus W (1998) Phytoplankton spring blooms in the southern Baltic Sea - spatio-temporal developments and long-term trends. J Plankton Res 20:1099-1117

Wasmund N, Pollehne F, Postel L, Siegel H, Zettler ML (2003) Biologische Zustandseinschätzung der Ostsee im Jahre 2003. Meereswiss Ber Warnemünde 60:1-87

Wesche A, Wiltshire KH, Hirche HJ (2007) Overwintering strategies of dominant calanoid copepods in the German Bight, southern North Sea. Mar Biol 151:1309-1320

Submitted: July 22, 2009; Accepted: February 15, 2010 Proofs received from author(s): April 28, 2010 